\title{
Moral and aesthetic considerations of humanity according to the Polish philosopher Mieczysław Wallis
}

\author{
Joanna Zegzuła-Nowak
}

\begin{abstract}
In this article, the author presents an overview of the $20^{\text {th }}$ century Polish humanist Mieczysław Wallis who searches for answers to the question of the essence of humanity. The philosopher saw it in human axiological activities building a world of specifically human creations thus giving Man a meaningful existence. An axiological perspective of human subjectivity - the search for the purpose and meaning of human existence in the implementation of aesthetical and ethical values can be seen as a methodological proposal worthy of deeper consideration which could facilitate solving modern ethical and bio-ethical problems.
\end{abstract}

Keywords: Mieczysław Wallis, Polish axiology in the $20^{\text {th }}$ century; aesthetic and moral considerations of humanity, values

\section{Introduction}

Philosophers, scientists, and artists have, for centuries, been searching for answers relating to the essence of humanity which contributes to the greatness and exceptionality of the human being in the world around him. Each effort seemed partial and thus cannot be considered as final. In science, particularly anthropology, features related exclusively to humans were related to activities like laughing and crying, the ability to perceive oneself from the outside (awareness of one's mirror reflection), skills to use tools, abstract thinking, auto-reflection, or the creation of culture, art and science.

In philosophy, this problem is presented in an even more complex way, with a wide range of approaches and perspectives based on ontology and epistemology. When dealing with human attributes, various classifications were evoked: feelings and senses (Sophism), the mind (Socrates, Kant), the soul (Plato), self-awareness (Locke, H. Plessner), personal dignity (Mounier, personalism), freedom (Sartre, existentialism), respecting values (moral and aesthetic) or morality in general.

Mieczysław Wallis (1895-1975), a $20^{\text {th }}$ century Polish humanist made an interesting, thought-provoking attempt at defining the essence of humanity. His concept founded several decades ago can be a guide for a modern person entangled in inter-personal relations and the axiological dilemmas related to them.

This thinker is a representative of the second generation of philosophers of the LvivWarsaw school, closely co-operating with and befriending many outstanding representatives of Polish science including Jan Łukasiewicz, Tadeusz Kotarbiński, Tadeusz Czeżowski, Maria and Stanisław Ossowski or Henryk Elzenberg. As an author, Wallis is mainly known for his studies in literature, aesthetics as well as art theory and its history. In my opinion, though, it is a too narrow and simplified image of his interests and scientific accomplishments. His numerous archived writings, unpublished so far, include notes, memories and letters indicate that his work was complex and rich. Among these items, a typescript entitled "Shortcuts" is worth particular attention as it contains Wallis' thoughts on philosophical anthropology, axiology and aesthetics. A picture of modern man is presented, 
searching for answers to and remedies for eternal human dilemmas, pains and inner desires. ${ }^{1}$ Wallis wrote about his inner intellectual desire to define reality as the complete embracement of reality, where a unique and complex world of human activities, aspirations and creations would play an important part. He described this in the following way: "For many years I have dreamt about building a great philosophical system. I have tried to define reality as the whole in which the human world constitutes a part. Reality being a number of layers where one follows out of the other" (Wallis, 1942-1944, p. 6). Mieczysław Wallis' considerations are worthy of attention as they encourage reflexion if and by how much a man should transform and adjust reality around him for his own needs in agreement with his nature. Thus the most important and yet unresolved problem arises - what is the essence of human nature; can it be specified adequately and finally. Does it determine the relationship between man and world and if so, in what way? Nowadays these issues are still important, especially with the fast development of science and on-going bioethical disputes and in ethics itself. Maybe Wallis' concept could be an effective trigger to work out axiological standards to solve them.

\section{Overcoming human subjectivity based on nature versus a sense of life's fragility and transience}

In his notes, Wallis puts human beings at the centre of his considerations, striving to define human characteristics and the significance of human activity in the world. He described humans as complex beings emerging from nature but also transcending it by stopping their inborn instincts and thus, according to Wallis, initiating development of human selfawareness, self-knowledge, including an awareness of the irreversibility of death. He wrote: "Man separated himself from nature and lost his instinctive self-confidence characteristic of animals. Man is unhappier than the animal because he knows he will die. In spite of this no one wishes to be an animal. Knowledge is more important for us than happiness" (Wallis, 1942-1944, p. 161).

From Wallis' notes it is clear that the issue of death accompanying humanity all the time and being a source of people's everlasting fear unsettled him from his early childhood. He encountered death in his immediate environment and described it in the following way: "One day when I was little, I learnt that a child I knew had died. This information made a huge impression on me. Till then I thought that only old people die. I was far from old and I thought I would have an infinitely long life ahead of me. Now it turned out that not everybody lives until old age and one can die even as a child. Having realised this, I was devastated" (Wallis, 1942-1944, p. 27). Taking into account the importance of human self-awareness related to one's finitude, as well as human irrational fear of an unavoidable death, Wallis formed his own concept of an attitude towards death which was worth adopting. The concept may be somewhat comforting to every person considering existential reflection related to the meaning and finitude of one's existence. Undoubtedly, being aware of one's finitude is a significant distinguishing factor of Man in the world. Each person has a time in their life when they realise with horror their transience and are faced with an absolute and irrevocable fact which end of life is and they feel afraid and frustrated. Wallis' recommendation is that instead of worrying about an unavoidable fate it is better to concentrate on what fate brings us and live life to the full. Perhaps human transience is a kind of price for the opportunity of a 'cognisant life' and of learning about its riches as opposed to a long-term naked existence. Wallis teaches his contemporaries that life is not about living for ever but about "experiencing

\footnotetext{
${ }^{1}$ Archived material belonging to M Wallis (mostly handwritten) are currently in the combined libraries in the Department of Philosophy and Sociology at Warsaw University, the Institute of Philosophy and Sociology of the Polish Science Academy (PAN) and the Polish Philosophical Society in Warsaw (catalogue entry PTF 04-38) where they were deposited by his daughter-in-law Elżbieta Grabska-Wallis.
} 
something special - life with all its various opportunities" (Wallis, 1942-1944, p. 55). Studies in thanatology which accompany analyses of the global human situation were present in Polish philosophy in the $20^{\text {th }}$ century, namely in the works of many outstanding humanists, including Henryk Elzenberg, Wallis' friend. Elzenberg emphasised the common belief that after death a person stops experiencing and receiving sensual impulses seems to be nonsensical rather that frightening. Such a post-death image, i.e. constant pressure of nothingness on human consciousness, is not only difficult to understand or imagine but also forms the basis of many aporias of epistemological and ontological nature. According to Elzenberg, death is complete loss of personality and consciousness, even of one's own existence, a transition from being to nothingness, a sort of non-existence. Moreover, by proclaiming the undoubted primacy of life over death, Elzenberg emphasised at the same time that life must have a certain quality and value. Therefore, he argued that: Blind attachment to life is a manifestation of misery (Elzenberg, 2002, p. 49.)

Such an image of death may also be inspiring in relation to settling modern arguments in applied ethics and bioethics. It can be treated as a proposal of a specified methodological perspective which allows specific moral dilemmas to be settled such as in social life and public life. These include medical staff activities such as allocation of funds and medical services, post-operative care, the importance of alleviating pain, the issue of medical futility or palliative care in the light of quality and comfort of human life and society's attitude to problems relating to quality of life with regards to prolonging and or shortening life - issues of euthanasia and abortion.

\section{The world of creations which are specifically human: aesthetic and moral conditioning of humanity}

Analysing the world of human creations, Wallis pointed out that even exclusively biological activities may gain a new context and meaning and assume sophisticated forms. For example, he wrote: "Man is the only being which invented making love without multiplying and multiplying without making love" (Wallis, 1942-1944, p. 161).

His further philosophical investigations led him to the conclusion that what distinguishes Man in the world is that Man is able to adopt a creative and interpretive approach towards his environment in which the key to finding its beauty and value lies in the surrounding world. Only Man can be sensitive to the aesthetic values of His surroundings. At this point it is worth mentioning that Wallis' axiology represents a psychological version of relationism (Rosner, 1975, pp. 160-161; Skoczyński \& Woleński, 2010, p. 440). He considered an aesthetic value to be the property of objects and does not exist independently of aesthetic objects but, as he stressed, is related to the subject's specific emotions evoked by the object. According to him the determined value is a special relation between the subject and the object and at the same time is related to evoking in the recipient psychological responses (positive aesthetic emotions). This relation only occurs in the human world thus the value's presence depends on human activity. The philosopher rejected objective and absolute axiological concepts stating that "the value is not [...] an independent being - real, ideal, intentional, nor something which exists in an everyday sense. It is valid and pertinent but it's only the ability of certain objects to evoke in perceivers intrinsic emotions which we call 'aesthetic experiences'. It is a property of these objects and does not exist outside them" (Wallis, 1968, p. 9).

In the light of his manuscripts, Wallis seems to be convinced that a person discovers his authenticity, accomplishment, inner rightness and integrity through an activity characteristic of humans. This includes openness to richness, the "colourfulness" of the world and intellectual - artistic and philosophical - creativity. This conviction is illustrated by one of Wallis' memories: "I knew a painter who left a girl he had seduced, but was unable to paint 
one brushstroke to please the public. I knew a historian who committed financial fraud, but was unable to change, to his advantage, a single comma in the text he quoted" (Wallis, 19421944, p. 166).

In his approach towards life the philosopher himself was extremely sensitive to all kinds of beauty and excellence in the worlds of human and natural creations. He could appreciate the visual similarities between art created by humans and nature. This approach is described in a piece entitled "The world's splendour" in which he wrote: "Carrot leaves are like the intricate paper cut-outs of the Kurpie region. Wine moustaches - rococo decorative style. Fragrant pea flowers - delicate watercolours. Poppy plants - vases from the Sung dynasty[...] How can one not be overjoyed at the sight of such magnificence! However, most people pass this glamor [sic] without noticing it. What a rich variety of colours our forest mushrooms have: boleti, buttermilks, alders, chanterelles! The colours range from pearl, grey, burdock, through lemon to red-brown, russet, chocolate, and chestnut. What lovely warm, bright and golden tones our common onion has. A common wall of red and brown bricks, interwoven with grey grout, shines in the sun like a wonderful Persian carpet. The world plays with thousands of colours" (Wallis, 1942-1944, p. 174). He also noticed similarities between moral and aesthetic beauty. He searched for beauty in people and their characters. Towards others he presented values such as respect, kindness, modesty and charity. As his student, Wanda Nowakowska remembers: "Professor Mieczysław Wallis was extremely modest, well-mannered, full of calm, quiet, deeply reconciled and focused on important issues. He radiated these characteristics thus not only shaping the behaviour of his students but also creating a special atmosphere in the whole department. [...] At the same time he was also extremely kind, always ready to give advice and support" (Nowakowska, 2001, p. 16).

Wallis' deliberations relating to human existence are undoubtedly related to the views of his contemporary Roman Ingarden. Ingarden was convinced that human beings excel when they go beyond the innate and are able to create their own axiological space. He wrote "Man transcends nature [...] and »with the power of his being « »creates the world which, although generally unchanged, takes on countless new historical faces «. [...] He then starts living beyond his strength and innate nature and creates for himself a new world, a new reality around himself and also inside himself. He creates a world of culture and nominates himself a humanity factor [...] He creates masterpieces which differ completely in essence from what can be found in the world as creations of Nature. The masterpieces are adjusted to the human spirit and represent his fulfilment" (Ingarden, 1987, pp. 13, 15). Moreover, Ingarden was convinced that axiological activity - a burden of overcoming his own biological being as a source of finding the meaning of his fate constitutes human greatness and thus becomes his life's obligation. His conclusion was as follows: "Human nature is about the constant effort to exceed the limits of animalism which exists in humans with humanity rising above it and man's role as the creator of values. Without this mission and effort to outgrow himself man sinks helplessly into pure animalism which is his death" (Wallis, 1942-1944, p. 161).

Thus Ingarden stressed, even more than Wallis, that axiological activity both specifically human and free from any biological pressure is an imperative for human action which makes existence worthwhile and meaningful. Similarly, Elzenberg concluded that culture is "a process of transforming man, and consequently his world, towards bigger values" (Elzenberg 2002 , p. 245). Thus it is "the warrant, the imperative, the purpose and the calling of man, the dome beyond whose pillars we should see ourselves and others, our lives and our actions" (Elzenberg, 1966b, p. 152).

Likewise, Wallis thought that activities exceeding the biological nature and routine of everyday life, requiring artistic effort to be an obligation of each man. He was convinced that these specific signs of human activity which are often specified as purely conventional, being 
strongly in contradiction to human biological conditioning constitute in fact the greatness of existence and human accomplishment in the world. He perversely concluded for example: "Religious or moral prohibitions resulting in suppression and sublimation, which »denigrate" man, were often an incentive in the rising of great cultures" (Wallis, 1942-1944, p. 161). Thus, every activity, primarily axiological, against one controlled instinctively, allows man to transcend his biological, prosaic being. In this light, he wrote, for example, of human experience in the field of art: "Any profound aesthetic experience is a marvel, stepping out of oneself, an »ecstasy«" (Wallis, 1942-1944, p. 174).

Wallis was upset that many people deprive themselves of these kinds of feelings, do not appreciate the singularity of their own being and do not implement it, living for the moment without inner aspirations, and abandon metaphysical concerns which are important for humanity. He wrote: "Man as an animal methaphysicum? The majority of people live from day by day, absorbed with making a living, void of any metaphysical concerns" (Wallis, 1942-1944, p. 161). This pessimistic diagnosis was supplemented with the comments of his contemporaries. He wrote: "Most people seem more attractive from a distance. When I was young, I thought that people and institutions are like Renaissance palaces, whose magnificent facades are the promises of equally wonderful interiors. Later, I found out that most of them are rather like those baroque churches, where beyond the impressive façade there is a meager interior. For many people, the circle of interests coincides with the circle of their interests" (Wallis, 1942-1944, p. 161). He, maybe, could see the reasons for such a situation not only in the insufficiencies of human nature and insensitivity to values, but also in the very world of axiological activities and creations. He realised that each human activity which is not determined by his own nature but aimed at "valuing" his world and inner being requires effort, hardship, and work and at times the results may be unsatisfactory, insufficient or even futile. He was convinced that perfectionist aspirations (a willingness to follow a chosen moral ideal) are unique in nature and extremely valuable for the person who has such goals, which often tends to be unattainable and a source of a lack of fulfilment and internal insufficiency. Wallis argued as follows: "The higher the standard a person sets himself, the more painful the feeling of discrepancy between an ideal and achievement. A person of strong moral character constantly feels how imperfect he is, a saint - his sinfulness" (Wallis, 1942-1944, p. 163). It appears that the philosopher did not seem to share the common held view among ethical representatives associated with perfectionism that an aspiration to perfection itself may be a sufficient target and an essence of moral activities, developing and enriching the inner person. In his opinion, human nature simply rebels against a vision of unattainable aim. Therefore, he thought that each scientist who is, with his work, on intimate terms with axiological issues should have an obligation or even a mission to draw other people's attention to the values and beauty of the world. Discovering these may not be natural for some people. However, he believed that each person should have an opportunity to be intimate with the world of axiological creations as they are not exclusively for the chosen ones i.e. experts and art connoisseurs or morality theoreticians. As one of his students, Jan Białostocki wrote: "Wallis was convinced that the values he so admired can and should be available to everyone" (Białostocki, 1983, p. 336). Realising that people can be indifferent to the values of the world, Wallis thought that they should be taught about beauty and the good which the world offers them such as they can perceive and appreciate it. He argued as follows: "Let us endeavour for as many people as possible to notice beauty, character or expression both in art masterpieces which are available to them and also in the most common things in their environment" (Wallis, 1968, p. 25). 


\section{Conclusion}

In his search for human specifics, Wallis depicted people in unusually many perspectives - as a being which auto-creates itself and searches (and perhaps even finds) its fullness in areas like art, aesthetics, philosophy and morality. Throughout his life he showed the importance and relevance of his own convictions. He set an example with his life as a person who deeply appreciated inner qualities and manifestations of human activities in aesthetics, art and ethics. Thus, remembering him after his death, Białostocki describes him as a "person [...] of exceptional kindness, honourable, extremely honest, [...] deeply and totally devoted to the values he believed in" (Białostocki, 1983, p. 339).

From a research perspective presented by a philosopher from Lodz in Poland, the problem of specifying the peculiarity of humanity and displaying fully the greatness of human beings is based on the acknowledgement of humans as beings with an open, creative and autocreative attitude towards themselves and their surrounding world.

The presented perspective view of human existence is so much more important and attractive since it indicates to modern man that his creative attitude may be interpreted not only as a mere expression of human creativity, imagination and mastery, but also as an expression of his moral inclination and ability to interpret the surrounding world. It may constitute the most important attribute of human existence, indicating the deepest inner human need to be rooted and to function in a world he co-creates putting it in a normative and axiological perspective, while and at the same time being fully responsible for it.

Joanna Zegzula-Nowak - researcher and teacher in Chair of Ethics of the Institute of Philosophy at the University of Zielona Gora; research interests: ethics, aesthetics, axiology, Polish contemporary philosophy.

Corresponding author:

Joanna Zegzuła-Nowak, the University of Zielona Góra, Al. Wojska Polskiego 71A, 65-762 Zielona Góra, Poland

Email: J.Zegzula-Nowak@ifil.uz.zgora.pl

\section{References}

BIAŁOSTOCKI, J. (1983): Wspomnienie pośmiertne, Mieczysław Wallis 1895-1975 [Posthumous recollections], Mieczysław Wallis 1895-1975. In: M. Wallis: Sztuki i znaki. Pisma semiotyczne [Art and signs: Semiotic writings]. Warszawa: Polski Instytut Wydawniczy, pp. 335-339.

ELZENBERG, H. (1966a): Nauka i barbarzyństwo [Science and barbarity]. In: H. Elzenberg: Wartość i człowiek. Rozprawy z humanistyki i filozofii [Value and humans. Discourse on humanities and philosophy]. Toruń: UMK, pp. 129-135.

ELZENBERG, H. (1966b): Wartość i człowiek. Rozprawy z humanistyki i filozofii [Value and humans: Discourse on humanities and philosophy]. Toruń: UMK.

ELZENBERG, H. (2002): Kłopot z istnieniem. Aforyzmy w porzadku czasu [Problems with existence: Aphorisms in the time order]. Torun: UMK.

INGARDEN, R. (1987): Książeczka o człowieku [A booklet about Man]. Kraków: Wydawnictwo Literackie.

NOWAKOWSKA, W. (2001): Sylwetki łódzkich uczonych. Profesor Mieczysław Wallis [Profiles of scientists from Lódź: Professor Mieczysław Wallis]. Łódź: Łódzkie Towarzystwo Naukowe.

PALACZ, R. (1999): Klasycy filozofii Polskiej [Classics in Polish philosophy]. Warszawa \& Zielona Góra: Zachodnie Centrum Organizacji, pp. 327-341, 397-406. 
ROSNER, K. (1975): Poglądy estetyczne Mieczysława Wallisa. Badania estetyczne a inne dziedziny jego działalności naukowej i krytycznej [The aesthetic views of Mieczysław Wallis: Aesthetic research and other areas of scientific and critical interest]. In: S. KrzemieńOjak \& W. Kalinowski (eds.): Studia z dziejów estetyki polskiej 1918-1939 [Studies in history of Polish aesthetics 1918-1939]. Warszawa: PWN, pp. 157-187.

SKOCZYŃSKI, J. \& Woleński J. (2010): Historia filozofii polskiej [A history of Polish philosophy]. Kraków: WAM.

WALLIS, M. (1942-1944): Skróty [Shortcuts]. In: Archiwum Połaczonych Bibliotek WFiS $U W$, IFiS PAN i PTF w Warszawie, 10(9), pp. 1-77.

WALLIS, M. (1968): Przeżycie $i$ wartość: pisma z estetyki nauki o sztuce 1931-1949 [Experience and value: writings in aesthetics from the science of art 1931-1949]. Kraków: Wydawnictwo Literackie. 